\title{
General features of persistent virus infections
}

\author{
C. A. Mims \\ B.Sc., M.D., F.R.C.Path. \\ Department of Microbiology, Guy's Hospital Medical School, London SEI 9RT
}

\begin{abstract}
Summary
Persistent virus infections are discussed from the virus point of view in terms of the bodily sites in which the infection persists. Glands and body surfaces are thought to be significant because they give the virus protection at the topographical level from immune forces, and because they are appropriate sites for the shedding of virus to the exterior. Germ cells are relevant sites because infection can thus be transmitted vertically from generation to generation in the host. The central nervous system, however, is generally a 'dead end' from which there is no shedding to the exterior. Persistence in blood may be relevant when continued arthropod transmission becomes possible. Most persistent viruses infect lymphoreticular tissues, and this is interpreted by suggesting that it results in an impaired immune response to the infecting virus, which in turn favours persistence.

It is suggested that the biological function of virus transformation and the integration of viral into host cell DNA is that it enables the infection to persist in the host and undergo reactivation. Papovaviruses, adenoviruses and oncornaviruses are considered from this point of view.
\end{abstract}

\section{Introduction}

There are three groups of viruses that seem to have an assured future. First, the respiratory viruses, which are evolving rapidly and entering their golden age as populations increase and give an almost unlimited supply of susceptible hosts living in the crowded conditions that favour transmission. Vaccines for all but the most pathogenic are an impossible dream because of the great variety of serotypes; chemotherapy seems a long way away, and the best hopes for control perhaps depend on the control of air quality and air movement in public places. Second, the viruses and the Chlamydia transmitted by the venereal route. Their transmission is greatly favoured by current habits of having multiple sexual partners, generally without mechanical (contraceptive) barriers to infection. These infectious agents also seem to be evolving rapidly and entering a successful period with unprecedented numbers of hosts engaged in harmless venery, suffering in the case of Chlamydia what we must call occasional colds in the urethra or cervix.

The third and most interesting group of successful viruses are those that persist in the body for long periods after initial infection, often for life.

\section{Bodily sites of persistence}

Let us consider the sites of the body in which viruses persist, and see whether these sites are of any particular significance (Table 1 ).

\section{Nervous system}

From the point of view of the infectious agent, there must be routes of discharge to the outside world if fresh hosts are to be infected. Herpes simplex and varicella-zoster viruses persist in dorsal root ganglia, and later in life, after reactivation in the ganglia, they spread down peripheral nerves to the body surface and initiate a lesion (cold sore or zoster) which is a source of infection for other individuals. In contrast, viruses that persist in the central nervous system would appear to have no opportunity to be shed to the outside world. Their persistence in this site can therefore be regarded as a 'dead end' from the virus point of view, except in the rare disease kuru where transmission of the causative agent takes place during cannibalistic consumption of infected brain. Such infections include subacute sclerosing panencephalitis (SSPE), progressive multifocal leucoencephalopathy (PML) and visna in sheep. The significance of this site is possibly that antiviral forces are less effectively mobilized in the central nervous system, thus favouring persistence. Perhaps the virus properties (non-productive infection, etc.) that are relevant to persistence elsewhere in more 'useful' sites in the body (see below) happen also to favour persistence in the central nervous system.

\section{Glands and body surfaces}

The viruses that persist in glands and other body surfaces discharging to the outside world are clearly able to spread to fresh individuals. This is as true for rabies virus in the acinar cells of the salivary gland of a vampire bat as it is for cytomegalovirus 
TABLE 1. Sites of infection of some persistent viruses

\begin{tabular}{|c|c|c|c|c|}
\hline & Site & Virus & Species & Significance of site \\
\hline \multirow{2}{*}{ Nervous system } & CBrain & $\begin{array}{l}\text { Measles (SSPE) } \\
\text { JC virus (PML) } \\
\text { Visna virus }\end{array}$ & $\begin{array}{l}\text { Man } \\
\text { Man } \\
\text { Sheep }\end{array}$ & $\begin{array}{l}\text { Immune forces less } \\
\text { effective? }\end{array}$ \\
\hline & Ganglia & $\begin{array}{l}\text { Herpes simplex } \\
\text { Varicella-zoster }\end{array}$ & $\begin{array}{l}\text { Man } \\
\text { Man }\end{array}$ & $\begin{array}{l}\text { Shedding of virus to } \\
\text { exterior }\end{array}$ \\
\hline \multirow{4}{*}{$\begin{array}{l}\text { Glands and body } \\
\text { surfaces }\end{array}$} & $\begin{array}{l}\text { Salivary gland (or } \\
\text { oropharyngeal } \\
\text { site) }\end{array}$ & $\begin{array}{l}\text { Cytomegalovirus } \\
\text { EB virus } \\
\text { Rabies virus }\end{array}$ & $\begin{array}{l}\text { Man, Mouse } \\
\text { Man } \\
\text { Vampire bat }\end{array}$ & \multirow{4}{*}{$\begin{array}{l}\text { Shedding of virus to } \\
\text { exterior }\end{array}$} \\
\hline & Kidney tubules & $\begin{array}{l}\text { Cytomegalovirus } \\
\text { BK, JC virus? } \\
\text { Polyoma virus }\end{array}$ & $\begin{array}{l}\text { Man } \\
\text { Man } \\
\text { Mouse }\end{array}$ & \\
\hline & Epidermis & Wart virus & Man & \\
\hline & Feather follicle & Marek's disease virus & Chicken & \\
\hline Germ cells & $\begin{array}{l}\text { Ovum } \\
\text { Sperm }\end{array}$ & $\begin{array}{l}\text { Leukaemia, mammary tumour, } \\
\text { LCM viruses } \\
\text { Mammary tumour virus }\end{array}$ & $\begin{array}{l}\text { Mouse } \\
\text { Mouse }\end{array}$ & $\begin{array}{l}\text { Mechanism for vertical } \\
\text { transmission }\end{array}$ \\
\hline \multirow[b]{2}{*}{ Blood } & Growth liver & Hepatitis B & Man & \multirow[b]{2}{*}{ Mosquito transmission? } \\
\hline & $\begin{array}{l}\text { ? growth site } \\
\text { Growth macrophages }\end{array}$ & $\begin{array}{l}\text { Simian haemorrhagic fever } \\
\text { virus } \\
\text { Equine infectious anaemia }\end{array}$ & $\begin{array}{l}\text { Patas monkey } \\
\text { Horse }\end{array}$ & \\
\hline \multicolumn{2}{|c|}{ Lymphoreticular tissue } & Many examples & Many species & $\begin{array}{l}\text { Mechanism for weakenin } \\
\text { antiviral forces }\end{array}$ \\
\hline
\end{tabular}

in the tubular epithelial cells in the kidney of an infected child. Warts often persist for many months, and large amounts of virus are present in the skin scales that are shed from the surface of the wart. Glands and surface epithelia are often infected, of course, by non-persistent 'hit and run' viruses, but the histological structure of these tissues favours persistence (Fig. 1). Circulating antibody fails to reach the lumenal surface of infected cells where virus is being released, and IgA antibodies, while they can attach to the virus surface and limit infection of other cells, are not capable of killing infected cells. Sensitized lymphocytes cannot attack the infected cell surface because in the absence of local inflammation or cell damage, they are unable to traverse the basement membrane and the epithelial cell sheet.

\section{Germ cells}

The viruses that persist as integrated genomes in germ cells, the viral genome being replicated as the cell divides, are in a very powerful position. All cells arising from the fertilized ovum will be infected, and thus all descendant generations, giving a type of vertical transmission in which it may be difficult to say which genes are viral and which are host. This is an ideal state of parasitism, it being of no conse- quence to the viral parasite whether it is present as a fully infectious entity or a nucleic acid remnant. If there is an 'Adam and Eve' origin for the species, then all individuals in the species will be infected $a b$ initio but if not, an initial period of horizontal transmission between individuals would be necessary. As argued elsewhere (Mims, 1975) it is conceivable that during the course of evolution many retroviruses have trod this path to integration into the host genome, because there is no selection against defectiveness and the presence of mere fragments of the viral genome as long as most individuals are infected.

\section{Blood}

It might seem a more difficult problem for an infecting virus to persist in the blood, there being powerful mechanisms for the removal of circulating foreign particles, but there are a number of examples. In many of these it seems likely that the infection has induced the formation of non-neutralizing or low avidity antibodies which favour persistence. One possible significance of this site is that it represents a long term source of infection for biting arthropods, who could thus continue to transmit the infection to fresh individuals. The persistent viraemia established in the Patas monkey by simian 


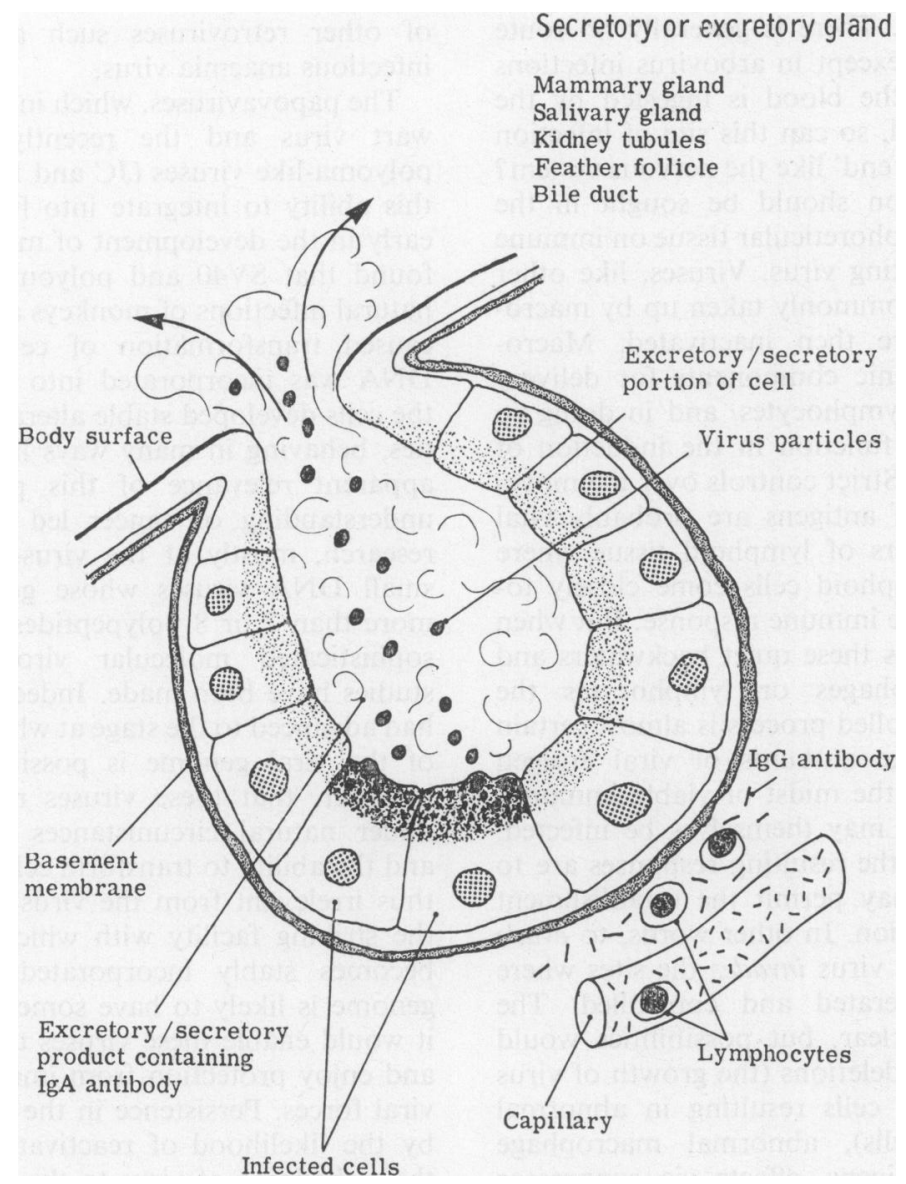

FIG. 1. Viral infection of cell surfaces facing the exterior.

TABle 2. Persistence of viruses in lymphoreticular tissues

\begin{tabular}{|c|c|c|}
\hline $\begin{array}{c}\text { Lymphoreticular } \\
\text { site }\end{array}$ & Virus & Host \\
\hline Lymphocytes & $\begin{array}{l}\text { Adenoviruses } \\
\text { EB virus } \\
\text { Cytomegalovirus } \\
\text { Leukaemia viruses } \\
\text { Visna virus } \\
\text { African swine fever virus } \\
\text { LCM virus }\end{array}$ & $\begin{array}{l}\text { Man } \\
\text { Man } \\
\text { Man etc. } \\
\text { Mouse etc. } \\
\text { Sheep } \\
\text { Pig } \\
\text { Mouse }\end{array}$ \\
\hline Macrophages & $\begin{array}{l}\text { Lactic dehydrogenase } \\
\text { virus } \\
\text { Aleutian disease virus } \\
\text { Equine infectious anaemia } \\
\text { virus } \\
\text { African swine fever virus } \\
\text { LCM virus }\end{array}$ & $\begin{array}{l}\text { Mouse } \\
\text { Mink } \\
\text { Horse } \\
\text { Pig } \\
\text { Mouse }\end{array}$ \\
\hline
\end{tabular}

haemorrhagic fever virus could have this significance, as would a viraemia that reappeared long after initial infection by any arbovirus, following reactivation in the host. Both hepatitis B (man) and equine infectious anaemia (a retrovirus infection of horses) are known to persist in the blood of the host for as long as $\mathbf{2 0}$ years. There have been suggestions that equine infectious anaemia is mechanically transmitted by biting arthropods. Could hepatitis B have arisen in this way, with spread via needles and scratches playing a secondary role in developed countries where there is lower exposure to biting arthropods? On the other hand, two other viruses that persist in the blood, lactic dehydrogenase virus (mice) and Aleutian disease virus (mink) are not known to be transmitted by arthropods, so perhaps the search for significance can at times be unrewarding.

\section{Lymphoreticular tissue}

The numerous persistent viruses that infect lymphoid tissue or macrophages are listed in Table 2. Scrapie, although it is not known to be a virus, could be added to this list. These viruses might seem at first sight to derive no benefit from persisting in 
lymphoreticular tissue. There is generally no route to the outside world, except in arbovirus infections when virus reaching the blood is ingested by the transmitting arthropod, so can this site of infection be regarded as a 'dead end' like the nervous system? Perhaps an explanation should be sought in the effect of growth in lymphoreticular tissue on immune responses to the infecting virus. Viruses, like other microorganisms, are commonly taken up by macrophages and many are then inactivated. Macrophages prepare antigenic components for delivery in small amounts to lymphocytes, and in doing so exercise a controlling function in the induction of the immune response. Strict controls over the movement and handling of antigens are probably vital in the quiet backwaters of lymphoid tissue where macrophages and lymphoid cells come closely together and generate the immune response. But when infectious virus reaches these quiet backwaters and multiplies in macrophages or lymphocytes the orderly and well controlled process is almost certain to be disturbed. Large amounts of viral antigen would be liberated in the midst of viable immunocompetent cells which may themselves be infected, and serious defects in the resulting responses are to be expected, which may permit the establishment of the persistent infection. In other words, to evade the immune forces the virus invades the sites where these forces are generated and controlled. The mechanisms are not clear, but possibilities would include specific $T$ cell deletions (the growth of virus in clonally expanding cells resulting in abnormal function in these cells), abnormal macrophage handling of virus antigens, effects via suppressor cells, and so on. Certainly immunosuppression is a common phenomenon in persistent virus infections, suggesting interference with immune function, and in some instances, such as EB and cytomegalovirus infection in man, there are auto-immune phenomena suggesting a degree of 'immunological chaos'.

\section{Significance of transformation by viruses}

Very little is understood about persistence of infection in the body at the virus-cell level. Quite probably adenoviruses, for instance, differ in this way from herpes simplex, and this in turn from other viruses of the herpes group. One very important mechanism by which a virus can evade antiviral forces and become persistent is by ceasing to produce virus particles and remaining in the host cell in the form of viral nucleic acid. Many persistent viruses show a striking reluctance to come out of the cell. The leukaemia viruses for instance possess a reverse transcriptase that enables them to form a DNA replica of their RNA genome, which then becomes part of the host cell genome. This is a central mechanism for the persistence of these and of other retroviruses such as visna and equine infectious anaemia virus.

The papovaviruses, which include SV40, polyoma, wart virus and the recently discovered human polyoma-like viruses (JC and BK viruses) also have this ability to integrate into host cell DNA. Quite early in the development of modern virology it was found that SV40 and polyoma viruses, which are natural infections of monkeys and mice respectively, caused transformation of cells in culture. Virus DNA was incorporated into host cell DNA, and the cells developed stable alterations in their properties, behaving in many ways like tumour cells. The apparent relevance of this phenomenon for the understanding of cancer led to a great surge in research, mostly at the virus-cell level. These are small DNA viruses whose genome codes for no more than 7 or 8 polypeptides, and in recent years sophisticated molecular virological and genetic studies have been made. Indeed, work on polyoma had advanced to the stage at which a partial mapping of the viral genome is possible. It is now clear, however, that these viruses rarely cause tumours under natural circumstances in the host species, and the ability to transform cells and cause cancer is thus irrelevant from the virus's point of view. Yee the striking facility with which papovavirus DNA becomes stably incorporated into the host celp genome is likely to have some significance. In fact 항. it would enable these viruses to persist in host cells and enjoy protection from immune and other antiviral forces. Persistence in the host, if accompanied by the likelihood of reactivation later in life with the reshedding of virus to the exterior, would be of immense biological significance. Could it be that this is the 'function' of papovavirus integration into host cell DNA, just as it is for leukaemia virus and other retroviruses? Adenoviruses also can integrate into host cell DNA, and transform cells, yet without causing tumours under natural circumstances. Here, too, the function of integration may be to facilitate persistence.

Thus, polyoma virus persists for life in the infected mouse, and with the aid of the factors illustrated in Fig. 1, is shed from saliva and urine for long periods. It would be interesting to see whether polyoma virus reactivates, as shown by an increase in shedding during pregnancy, or in old age. $\mathrm{BK}$ and $\mathrm{JC}$ viruses persist in the human host after primary infection and can later be reactivated and excreted in infectious form in urine in the immunosuppressed renal allograft recipient. Epithelial cells in the kidney tubules or ureter are likely sites for persistence (Coleman. 1975) and the presence of IgM antibodies to BK virus in many normal people (Flower, Banatvala and Christie, 1977) suggests the continued release of viral antigens. To take another example, human 
wart virus also is reactivated in immunosuppressed renal allograft recipients, leading to the appearance of multiple warts. It seems possible that after initial infection, which often appears to be subclinical (Lee and Eisinger, 1976), the virus persists, possibly as integrated DNA, in stem cells in the epidermis. In the wart itself it is known that viral DNA is present in epidermal cells, but antigens and infectious virus are only formed as the cells keratinize and approach the skin surface.

\section{Importance of persistent virus infections}

Why are persistent virus infections important? (Table 3).

TABLE 3. Importance of persistent virus infections

\begin{tabular}{cl}
\hline 1. Reactivation & $\begin{array}{l}\text { Renal transplant patients } \\
\text { Hodgkin's disease } \\
\text { Old age }\end{array}$ \\
$\begin{array}{c}\text { 2. Immunopathological } \\
\text { damage }\end{array}$ & $\begin{array}{l}\text { Circulating immune complexes } \\
\text { Most good examples in animal } \\
\text { models }\end{array}$ \\
$\begin{array}{c}\text { 3. Association with } \\
\text { tumours }\end{array}$ & $\begin{array}{l}\text { Leukaemia viruses } \\
\text { Burkitt's lymphoma } \\
\text { Carcinoma of cervix }\end{array}$ \\
$\begin{array}{c}\text { 4. Persisence enables } \\
\text { parasite to be } \\
\text { successful }\end{array}$ & $\begin{array}{l}\text { Example of varicella-zoster } \\
\text { Prehistoric man } \\
\text { Isolated communities }\end{array}$ \\
\hline
\end{tabular}

1. They can reactivate, as shown for immunosuppressed renal transplant recipients in Table 4. They also reactivate in certain diseases characterized by immunosuppression, as illustrated by the zoster eruptions seen in patients with Hodgkin's disease. A weakening of immune defences is also a feature of old age, whether in man or mouse, and the frequency of zoster rises sharply in patients over the age of 50 years. It would be of very great interest to determine whether the other persistent virus infections, for instance $\mathrm{BK}, \mathrm{JC}$, adenovirus or hepatitis $\mathrm{B}$, reactivate in old age.
2. Persistent viruses can cause progressive disease. This is often immuno-pathological in nature, such as the glomerulonephritis and vasculitis seen in lymphocytic choriomeningitis infection in mice and Aleutian disease virus infection in mink. In these persistent infections circulating immune complexes are formed in antigen excess and are responsible for the lesions.

3. Persistent viruses can also cause tumours. Certain persistent herpes viruses can either cause tumours experimentally or are strongly implicated in naturally occurring tumours. The leukaemia and mammary tumour viruses cause tumours in certain species, depending on host genetics and hormonal status.

4. Persistence is important from the virus's point of view, enabling it to be a successful parasite. The example of varicella-zoster makes this clear. During childhood infection with chickenpox, virus ascends to the dorsal root ganglia of sensory nerves supplying the affected skin areas and stays there in a noninfectious state after recovery and the elimination of virus from the rest of the body. The disease, chickenpox, disappears from the community. At a later stage, when infected individuals are old and the immune responses that control the persistent infection have weakened, the virus reactivates randomly in one of the ganglia and spreads down the peripheral nerve to the skin, causing a crop of infectious vesicles. The fresh set of susceptible individuals who have arisen in the community can now be infected with chickenpox. Chickenpox thus maintains itself in small communities without reintroduction from the outside. In the palaeolithic period about 100000 years ago, and during most of human evolution, men have lived in small groups of 20-50 indviduals, contact with other groups being infrequent. A virus such as varicella-zoster can maintain itself in such a community, whereas a virus such as measles or poliomyelitis could not do so. Hence persistent viruses are probably old associates of man. They are well

TABLE 4. Some common persistent virus infections of man

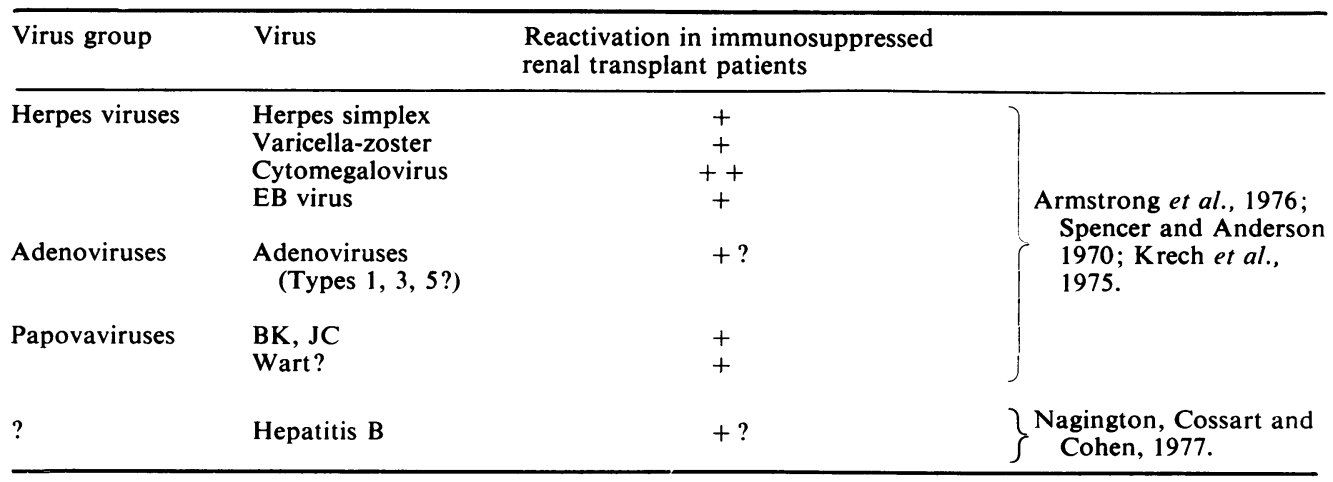


adapted parasites capable of maintaining themselves in small groups of individuals. During an expedition into the Amazon basin a number of isolated Indian tribes were discovered, many of whom had little or no contact with the outside world. Serum from people in these tribes was found to have antibodies to persistent viruses such as herpes simplex, varicellazoster, EB, hepatitis $B$ and cytomegalovirus, but there were no antibodies to non-persistent 'hit and run' viruses such as poliomyelitis, measles and influenza viruses (Black et al., 1974).

Finally, it is clear that when an infectious agent multiplies in the host, induces immune responses, and these immune responses fail to disinfect the tissues, then some trouble is to be expected with the development of vaccines. One of the successful vaccines against viruses of the herpes group is that for Marek's disease, which is a living attenuated virus vaccine. It causes a persistent infection in the chicken host and thus protects against infection with the wild type virus. When the vaccine virus is live and persists in tissues, there are worries about reactivation or tumour induction later in life. Perhaps the live vaccine virus manages to persist in the body because, like its 'wild' counterpart, it invades lymphoreticular tissues as discussed above. If this is so, the future lies in killed virus vaccines, and these may come when we are able to induce the right type of immune response to the right virus antigen. Until then, man will keep his persistent viruses.

\section{References}

Armstrong, J.A., Evans, A.S., RaO, N. \& Ho, M. (1976) Virus infections in renal transplant patients. Infection and Immunity, 14, 970.

Black, F.L., Hierholzer, W.J., Pinheiro, F., Evans, A.S., Woodall, J.P., Opton, E.M., Emmons, J.E., West, B.S., Edsall, G., Downs, W.G. \& Wallace, G.D. (1974) Evidence for persistence of infectious agents in isolated human populations. American Journal of Epidemiology, $100,230$.

Coleman, D.J. (1975) The cytodiagnosis of human polyoma virus infection. Acta cytologica, 19, 93.

Flower, A.J., Banatvala, J.E. \& Christie, I.L. (1977) BK antibody and virus-specific IgM responses in renal transplant recipients, patients with malignant disease, and healthy people. British Medical Journal, 2, 220.

Krech, U., Jung, M., Price, P.C., Thiel, G., Sege, D. \& REUTTER, F. (1975) Virus infections in renal transplant recipients. Zeitschrift für Immunitätsforschung, Allergie und klinische Immunologie, 148, 341.

LeE, A.K.Y. \& EISINGer, M. (1976) Cell mediated immunity (CMI) to human wart virus and wart-associated tissue antigens. Clinical and Experimental Immunology, 26, 419.

Mims, C.A. (1975) The meaning of persistent infections in nature. Bulletin of the World Health Organization, No. 52, 747.

Nagington, J., Cossart, Y.E. \& Cohen, B.J. (1977) Reactivation of hepatitis $B$ after transplant operations Lancet, i, 558.

SPENCER, E.S. \& ANDERson, K.H. (1970) Clinically evident, non-terminal infections with herpes viruses and the wart virus in immunosuppressed renal allograft recipients British Medical Journal, 3, 251. 